\title{
Analysis of Chondroitin/Dermatan Sulfate Microstructure in Cultured Vascular Smooth Muscle Cells after Exposure to Lead and Cadmium
}

\author{
Yasuyuki Fujiwara, ${ }^{a}$ Chika Yamamoto, ${ }^{a}$ Toshiyuki Kaji, ${ }^{*, a}$ and Anna H. Plaas ${ }^{b}$ \\ ${ }^{a}$ Department of Environmental Health, Faculty of Pharmaceutical Sciences, Hokuriku University, Ho-3 Kanagawa-machi, Kanazawa \\ 920-1181, Japan and 'Department of Internal Medicine, College of Medicine, University of South Florida, 12901 Bruce B. Downs \\ Blvd., Tampa, FL 33612-4799, U.S.A.
}

(Received July 23, 2003; Accepted July 25, 2003)

\begin{abstract}
Chondroitin/dermatan sulfate chains consist of a repeating disaccharide unit of glucuronic acid (GlcA)/ iduronic acid (IdoA) and $\mathrm{N}$-acetylgalactosamine (GalNAc) with or without $O$-sulfation at the $\mathrm{C}-4$ and C-6 position of GalNAc and at the C-2 position of IdoA. Lead and cadmium influence the synthesis of chondroitin/dermatan sulfate proteoglycan core proteins in vascular smooth muscle cells when the cell density is high and low, respectively. However, it has been unclear whether the metals influence the synthesis of chondroitin/dermatan sulfate chains. In the present study, it was shown that lead inhibits the formation of

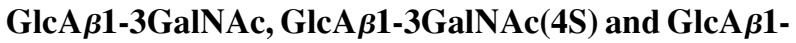
3GalNAc(6S) in dense cells, whereas cadmium inhibits the formation of GlcAs1-3GalNAc(4S) and

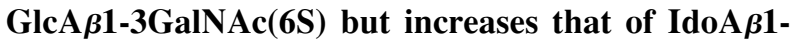
3GalNAc(4S) in the sparse cells. The present data support the hypothesis that lead and cadmium may influence the composition of chondroitin/dermatan sulfate in atherosclerotic vascular wall depending on the density of vascular smooth muscle cells.
\end{abstract}

Key words — cadmium, glycosaminoglycan, lead, proteoglycan, vascular smooth muscle cell, atherosclerosis

\section{INTRODUCTION}

Arterial chondroitin/dermatan sulfate proteoglycans have multiple functions, including collagen fibrillogenesis, ${ }^{1)}$ retention of cytokines ${ }^{1)}$ and lipoproteins, ${ }^{2)}$ and activation of heparin cofactor II. ${ }^{3)}$ The

\footnotetext{
*To whom correspondence should be addressed: Department of Environmental Health, Faculty of Pharmaceutical Sciences, Hokuriku University, Ho-3 Kanagawa-machi, Kanazawa 9201181, Japan. Tel. \& Fax: +81-76-229-6208; E-mail: t-kaji@ hokuriku-u.ac.jp
}

chondroitin/dermatan sulfate chains play an important role in these functions of the proteoglycans. A large chondroitin sulfate proteoglycan versican and small dermatan sulfate proteoglycans biglycan and decorin are synthesized and secreted by vascular smooth muscle cells in the arterial wall. ${ }^{4)}$ Chondroitin/dermatan sulfate proteoglycans are composed of distinct core proteins linked to chondroitin sulfate (versican) or dermatan sulfate (decorin and biglycan) chains that consist of alternating hexuronic acid and $N$-acetylgalactosamine (GalNAc) residues. ${ }^{5)}$ Dermatan sulfate chains are heterogeneous in their extent of posttranslational modifications such as the conversion of glucuronic acid (GlcA) to its epimer iduronic acid (IdoA), and $O$-sulfation at the C-4 and C-6 position of GalNAc (GalNAc(4S) and GalNAc(6S), respectively), and the $\mathrm{C}-2$ position of IdoA. ${ }^{6}$ The chondroitin sulfate chains are also heterogeneous, but they lack IdoA residues.

Lead and cadmium are toxic heavy metals that have been shown to induce vascular disorders such as atherosclerosis in epidemiological and experimental studies. ${ }^{7-10)}$ Our cell culture studies indicate that lead and cadmium influence fibrinolytic activity ${ }^{11)}$ and the monolayer maintenance ${ }^{12)}$ of vascular endothelial cells, which are both important events in the initiation of atherosclerosis. ${ }^{13)}$ Cadmium directly injuries vascular endothelial cell monolayers, ${ }^{12}$ while lead inhibits the repair of wounded monolayers by induction of a lower response of the cells to endogenous fibroblast growth factor- 2 as a result of inhibition of heparan sulfate proteoglycan synthesis. ${ }^{14-16)}$ On the other hand, lead and cadmium cause functional abnormalities in vascular smooth muscle cells, such as proliferation ${ }^{17,18)}$ and fibrinolytic activity. ${ }^{1920)}$ Recently, we found that lead selectively inhibits the synthesis of versican in vascular smooth muscle cells at a high cell density, ${ }^{21)}$ whereas cad- 
mium specifically induces that of biglycan and decorin at a low cell density, ${ }^{22)}$ without influence on the elongation of chondroitin/dermatan sulfate. However, it is unclear whether the heavy metals actually change the composition of chondroitin/dermatan sulfate.

In the present study, to address this question, dense and sparse cultures of bovine aortic smooth muscle cells were exposed to lead and cadmium, respectively, and the disaccharide units of chondroitin/dermatan sulfate chains synthesized by the cells were analyzed by the fluorophore-assisted carbohydrate electrophoresis.

\section{MATERIALS AND METHODS}

Materials — Vascular smooth muscle cells derived from bovine aorta were a gift from Dr. Yasuo Suda (Graduate School of Sciences and Engineering, Kagoshima University, Kagoshima, Japan). Dulbecco's modified Eagle medium (DMEM) and ASF 301 medium were purchased from Nissui Pharmaceutical (Tokyo, Japan) and Ajinomoto (Tokyo, Japan), respectively. Fetal bovine serum was obtained from Equitech-Bio (Kerrville, TX, U.S.A.). Tissue culture dishes and plates were obtained from Corning (NY, U.S.A.). The gel electrophoresis apparatus was from BioRad (Hercules, CA, U.S.A.). MicroCon 3 (3000 MW cut-off) ultrafiltration devices were purchased from Millipore (Billerica, MA, U.S.A.). 2-Aminoacridone hydrochloride was from Molecular Probes (Eugene, OR, U.S.A.). Proteasefree chondroitinase $\mathrm{ABC}$ (EC 4.2.2.4 derived from Proteus vulgaris) and chondroitinase ACII (EC 4.2.2.5 derived from Arthrobacter aurescens) were from Seikagaku (Tokyo, Japan). Proteinase K (fungal) was purchased from Invitrogen (Carlsbad, CA, U.S.A.). Sephadex G-50 fine was from Amersham Biosciences (Piscataway, NJ, U.S.A.). Sodium cyanoborohydride (95\% pure), sodium acetate, ammonium hydroxide, acetic acid, dimethylsulfoxide, and D-galactose 6-sulfate (gal6S) were from Sigma Aldrich (St. Louis, MO, U.S.A.). Lead nitrate, cadmium chloride and other reagents were from Nacalai Tesque (Kyoto, Japan).

Cell Culture and Sample Preparation —_ Vascular smooth muscle cells were cultured in DMEM supplemented with $10 \%$ fetal bovine serum in $100 \mathrm{~mm}$ dishes at $37^{\circ} \mathrm{C}$ in a humid atmosphere of $5 \% \mathrm{CO}_{2}$ in air until confluence. They were then transferred into $100 \mathrm{~mm}$ dishes at $1 \times 10^{4}$ cells $/ \mathrm{cm}^{2}$ and cultured for $24 \mathrm{hr}$ ('sparse cultures') or until confluence ('dense cultures') in DMEM supplemented with $10 \%$ fetal bovine serum. The medium was discarded and the cell layer was washed twice with serum-free ASF 301 medium. The dense and sparse cultures were then incubated at $37^{\circ} \mathrm{C}$ for $24 \mathrm{hr}$ in $6 \mathrm{ml}$ of fresh serum-free ASF 301 medium with lead nitrate $(5 \mu \mathrm{M})$ and cadmium chloride $(0.1 \mu \mathrm{M})$, respectively. After incubation, the conditioned medium was harvested and digested at $60^{\circ} \mathrm{C}$ for $18 \mathrm{hr}$ with $800 \mu \mathrm{g} / \mathrm{ml}$ of proteinase $\mathrm{K}$ in sodium acetate buffer, $\mathrm{pH}$ 7.2. The cell layer was washed twice with $\mathrm{Ca}, \mathrm{Mg}$-free phosphate-buffered saline and digested with proteinase $\mathrm{K}$ in a similar way. The digests, after inactivation of the proteinase at $100^{\circ} \mathrm{C}$ for $10 \mathrm{~min}$, were chromatographed on Sephadex G-50 columns equilibrated with distilled water; the high molecular mass fraction was collected and centrifuged through MicroCon 3 ultrafiltration devices. The materials retained on the filter were washed twice with distilled water to remove buffer salts, amino acids and glucose, and were recovered in distilled water. They were divided into two aliquots and dried for further processing.

Depolymerization of Chondroitin/Dermatan Sulfate Chains and Fluorophore-Assisted Carbohydrate Electrophoresis — Dried samples were dissolved in $75 \mu \mathrm{l}$ of $0.1 \mathrm{M}$ ammonium acetate $\left(\mathrm{pH}\right.$ 7.3) and digested for $18 \mathrm{hr}$ at $37^{\circ} \mathrm{C}$ with chondroitinase ACII $(1 \mathrm{U} / \mathrm{ml})$ or with both chondroitinase $\mathrm{ABC}(0.2 \mathrm{U} / \mathrm{ml})$ and chondroitinase ACII $(1 \mathrm{U} /$ $\mathrm{ml})$. The chondroitin/dermatan sulfate hydrolase products were recovered with MicroCon 3. Fluorotagging was carried out as described previous$1 \mathrm{y},{ }^{23,24)}$ and separated on the separating gels $(20 \%$ acrylamide, $2.5 \%$ glycerol and $45 \mathrm{mM}$ Tris acetate, $\mathrm{pH} 7.0,0.75 \mathrm{~mm}$ thick) with a stacking gel $(7.7 \%$ acrylamide, $1.7 \%$ agarose, $5 \%$ glycerol and $45 \mathrm{mM}$ Tris acetate, $\mathrm{pH}$ 7.0). Electrophoresis was carried out in the running buffer $(0.1 \mathrm{M}$ Tris-borate buffer, $\mathrm{pH}$ 8.3) at $4^{\circ} \mathrm{C}$. The fluorescent images were displayed in a gel documentation system (Atto, AE6914) and recorded as TIFF files. The bands of chondroitin/dermatan sulfate disaccharide units were quantitatively analyzed by NIH Image Analyses Software using the bands of gal6S as standard.

Statistical Analysis — Data were analyzed for statistical significance by analysis of variance (ANOVA) and Bonferroni's multiple $t$-test. $p$-Values of less than 0.05 were considered to indicate statistically significant differences. 


\section{RESULTS AND DISCUSSION}

Since lead inhibits the synthesis of versican in vascular smooth muscle cells with high cell density, ${ }^{21)}$ whereas cadmium induces that of biglycan and decorin with low cell density, ${ }^{22}$ dense and sparse cultures of the cells were exposed to lead and cadmium, respectively. Figure 1 shows the morphological appearance of dense (Fig. 1A) and sparse (Fig. 1C) cells after exposure to lead at $5 \mu \mathrm{M}$ (Fig.1B) or cadmium at $0.1 \mu \mathrm{M}$ (Fig. 1D) for $24 \mathrm{hr}$. There was a distinct difference in cell density between dense and sparse cultures; however, no degenerative change was observed, even after exposure to the heavy metals.

Figure 2 shows typical gel images of fluorophore-assisted carbohydrate electrophoresis of disaccharide units derived from chondroitin/dermatan sulfate isolated from the cell layer, as well as the conditioned medium of vascular smooth muscle cells before and after exposure to lead or cadmium. In the cell layer of dense and sparse cultures, GlcA/IdoA $\beta 1$-3GalNAc(4S) and GlcA/IdoA $\beta 1$ $3 \mathrm{GalNAc}(6 \mathrm{~S})$ were generated by digestion with both chondroitinase $\mathrm{ABC}$ and ACII; GlcA/IdoA $\beta 1$ 3 GalNAc was detected in sparse cells (Figs. 2A and $2 \mathrm{E})$. In addition, GlcA $\beta 1-3 \mathrm{GalNAc}(4 \mathrm{~S})$ and GlcA $\beta 1$ $3 \mathrm{GalNAc}(6 \mathrm{~S})$ were generated by digestion with only chondroitinase ACII (Figs. 2B and 2F); GlcA $\beta 1$ 3 GalNAc was also detected in sparse cells (Fig. 2F). Since IdoA-containing disaccharides cannot be generated by digestion with chondroitinase ACII, the content of IdoA-containing disaccharides was estimated by subtracting the content of GlcA $\beta 1$ 3 GalNAc(4S) and GlcA $\beta 1-3 \operatorname{GalNAc}(6 \mathrm{~S})$ and GlcA $\beta 1$-3GalNAc from that of the GlcA/IdoA $\beta 1$ $3 \mathrm{GalNAc}(4 \mathrm{~S})$ and GlcA/IdoA $\beta 1-3 \mathrm{GalNAc}(6 \mathrm{~S})$ and GlcA/IdoA $\beta 1$-3GalNAc (see Tables 1 and 2). The results indicate that the disaccharide units of chondroitin/dermatan sulfate detected in the cell layer of vascular smooth muscle cells are GlcA $\beta 1$ 3 GalNAc(4S), GlcA $\beta 1-3 \operatorname{GalNAc}(6 \mathrm{~S})$ and IdoA $\beta 1$ $3 \mathrm{GalNAc}(4 \mathrm{~S})$ in dense cells and GlcA $\beta 1-3 \mathrm{GalNAc}$, GlcA $\beta 1-3 \operatorname{GalNAc}(4 \mathrm{~S})$, GlcA $\beta 1-3 \operatorname{GalNAc}(6 \mathrm{~S})$ and IdoA $\beta 1-3$ GalNAc(4S) in sparse cells before and after exposure to lead or cadmium, respectively. Similarly, it was shown that the conditioned medium of both dense and sparse cultures had GlcA $\beta 1$ 3GalNAc, GlcA $\beta 1-3$ GalNAc(4S), GlcA $\beta 1$ $3 \mathrm{GalNAc}(6 \mathrm{~S})$ and IdoA $\beta 1-3 \mathrm{GalNAc}(4 \mathrm{~S})$ before and after exposure to lead or cadmium, respectively (Figs. 2C, 2D, 2G and 2H. Calculated data are in

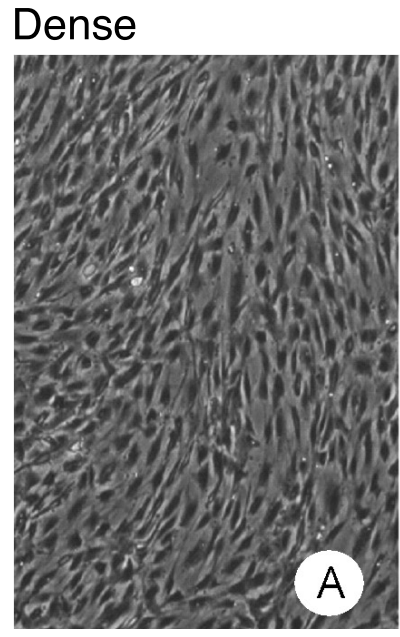

Control

\section{Sparse}

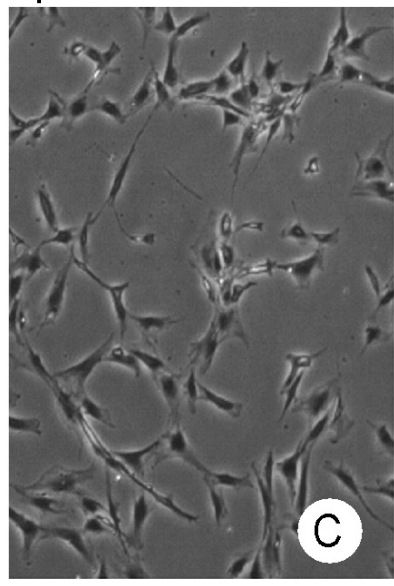

Control

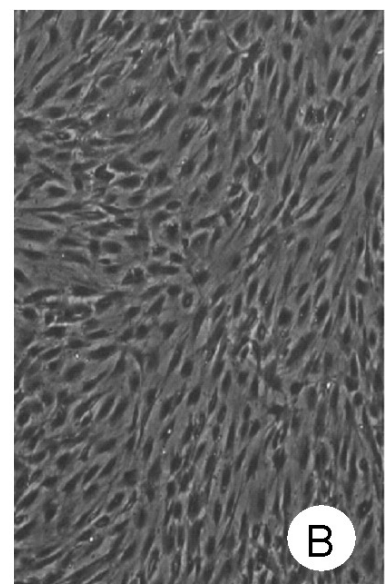

$5 \mu \mathrm{M}$ Lead

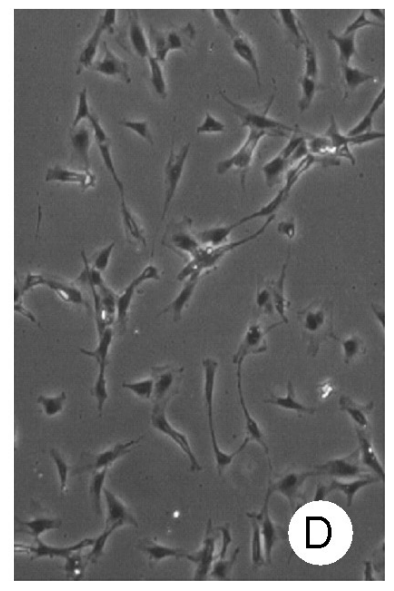

$0.1 \mu \mathrm{M}$ Cadmium
Fig. 1. Morphological Appearance of Dense and Sparse Vascular Smooth Muscle Cells after Exposure to Lead or Cadmium $(\times 40)$

A, dense vascular smooth muscle cells (control); B, dense vascular smooth muscle cells with lead (5 $\mu \mathrm{M})$ for $24 \mathrm{hr}$; $\mathrm{C}$, sparse vascular smooth muscle cells (control); D, sparse vascular smooth muscle cells treated with cadmium $(0.1 \mu \mathrm{M})$ for $24 \mathrm{hr}$.

Tables 1 and 2). Since versican has no IdoA-containing disaccharide units, it is postulated that IdoA $\beta 1-3 \mathrm{GalNAc}(4 \mathrm{~S})$ is derived from biglycan/ decorin, whereas GlcA $\beta 1-3$ GalNAc, GlcA $\beta 1$ $3 \mathrm{GalNAc}(4 \mathrm{~S})$ and GlcA $\beta 1-3 \mathrm{GalNAc}(6 \mathrm{~S})$ can be derived mainly from versican.

Table 1 shows the disaccharide composition of chondroitin/dermatan sulfate derived from dense vascular smooth muscle cells before and after exposure to lead. Although no marked change was observed in the cell layer, lead decreased the amount of GlcA $\beta 1-3 \mathrm{GalNAc}$, GlcA $\beta 1-3 \mathrm{GalNAc}(4 \mathrm{~S})$ and GlcA $\beta 1-3$ GalNAc(6S) in the conditioned medium. 

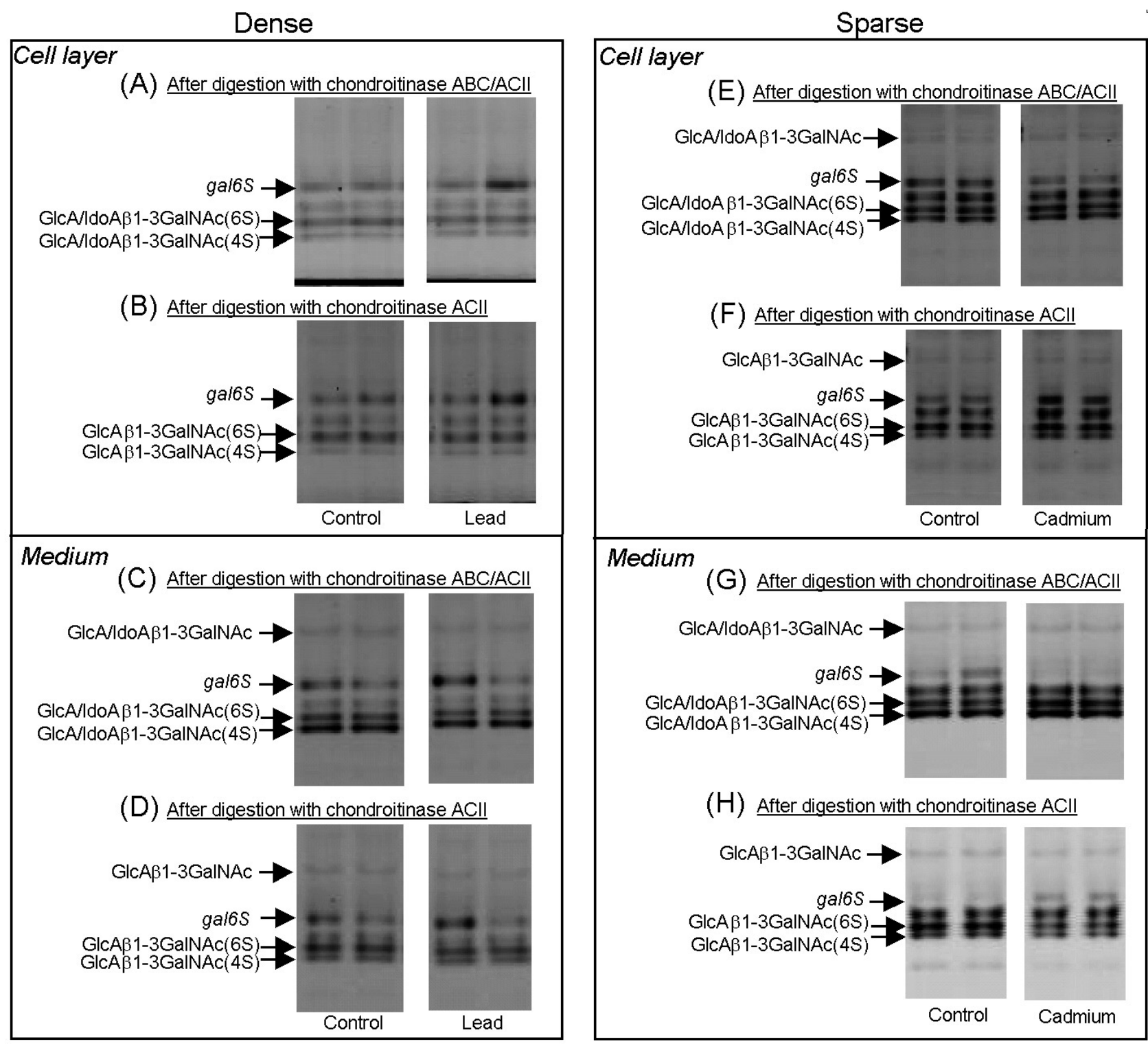

Fig. 2. Fluorophore-Assisted Carbohydrate Electrophoresis Analysis of Chondroitin/Dermatan Sulfate from the Cell Layer and the Conditioned Medium of Dense and Sparse Vascular Smooth Muscle Cells before and after Treatment with Lead or Cadmium

Dense (left panels) and sparse (right panels) cultures of bovine aortic smooth muscle cells were incubated at $37^{\circ} \mathrm{C}$ for $24 \mathrm{hr}$ with lead $(5 \mu \mathrm{M})$ and cadmium $(0.1 \mu \mathrm{M})$, respectively. The samples were prepared from one and three $100 \mathrm{~mm}$-dishes in dense culture and sparse culture, respectively.

Since these disaccharide units are a component of chondroitin sulfate, the decrease is regarded as a reflection of reduced versican synthesis by lead. ${ }^{21)}$ On the other hand, the amount of IdoA $\beta 1$ $3 \mathrm{GalNAc}(4 \mathrm{~S})$ was unaffected by lead. Since IdoA $\beta 1$ $3 \mathrm{GalNAc}(4 \mathrm{~S})$ is one of the major components of dermatan sulfate, this suggests that lead influences neither the synthesis of biglycan/decorin core proteins ${ }^{21)}$ nor the formation of the dermatan sulfate chains. However, the ratio of GlcA $\beta 1-3 \mathrm{GalNAc}(4 \mathrm{~S})$ to GlcA $\beta 1-3 \mathrm{GalNAc}(6 \mathrm{~S})$ was unaffected by lead, indicating that the metal does not influence the sulfation of GlcA $\beta 1-3$ GalNAc in chondroitin/ dermatan sulfate chains. Taken together, it is suggested lead inhibits the synthesis of versican core protein but does not influence the formation of chondroitin/dermatan sulfate chains of versican, biglycan or decorin in dense vascular smooth muscle cells.

Table 2 shows the disaccharide composition of chondroitin/dermatan sulfate derived from sparse vascular smooth muscle cells before and after exposure to cadmium. In the conditioned medium, cadmium significantly decreased the amount of GlcA $\beta 1$ 3 GalNAc(4S) and GlcA $\beta 1-3$ GalNAc(6S). In addi- 
Table 1. Disaccharide Composition of Chondroitin/Dermatan Sulfate in Dense Vascular Smooth Muscle Cells after Exposure to Lead

\begin{tabular}{|c|c|c|}
\hline \multirow[b]{2}{*}{ Component } & \multicolumn{2}{|c|}{ Disaccharide amount $\left(\mathrm{pmol} / \mathrm{cm}^{2}\right)$} \\
\hline & Control & $5 \mu \mathrm{M}$ Lead \\
\hline \multicolumn{3}{|l|}{ Cell layer } \\
\hline GlcA $\beta 1-3$ GalNAc & ND & ND \\
\hline $\operatorname{GlcA} \beta 1-3 \operatorname{GalNAc}(4 \mathrm{~S})$ & $24.2 \pm 2.18$ & $27.5 \pm 0.55$ \\
\hline GlcA $\beta 1-3$ GalNAc(6S) & $60.5 \pm 4.55$ & $59.8 \pm 1.27$ \\
\hline $4 \mathrm{~S} / 6 \mathrm{~S}$ & 0.40 & 0.46 \\
\hline $\operatorname{IdoA} \beta 1-3 \mathrm{GalNAc}(4 \mathrm{~S})$ & $6.91 \pm 2.18$ & $6.18 \pm 1.82$ \\
\hline \multicolumn{3}{|l|}{ Conditioned medium } \\
\hline GlcA $\beta 1-3$ GalNAc & $16.5 \pm 1.45$ & $11.6 \pm 0.18^{*}$ \\
\hline GlcA $\beta 1-3$ GalNAc(4S) & $96.4 \pm 22.7$ & $62.4 \pm 2.55^{*}$ \\
\hline GlcA $\beta 1-3$ GalNAc(6S) & $116 \pm 13.8$ & $85.1 \pm 4.55^{*}$ \\
\hline $4 \mathrm{~S} / 6 \mathrm{~S}$ & 0.83 & 0.73 \\
\hline $\operatorname{IdoA} \beta 1-3 \mathrm{GalNAc}(4 \mathrm{~S})$ & $73.3 \pm 10.7$ & $74.7 \pm 3.09$ \\
\hline
\end{tabular}

Table 2. Disaccharide Composition of Chondroitin/Dermatan Sulfate in Sparse Vascular Smooth Muscle Cells after Exposure to Cadmium

\begin{tabular}{|c|c|c|}
\hline \multirow[b]{2}{*}{ Component } & \multicolumn{2}{|c|}{ Disaccharide amount $\left(\mathrm{pmol} / \mathrm{cm}^{2}\right)$} \\
\hline & Control & $0.1 \mu \mathrm{M}$ Cadmium \\
\hline \multicolumn{3}{|l|}{ Cell layer } \\
\hline GlcA $\beta 1-3$ GalNAc & $1.67 \pm 0.42$ & $1.29 \pm 0.09^{*}$ \\
\hline GlcA $\beta 1-3$ GalNAc(4S) & $8.58 \pm 0.09$ & $9.78 \pm 0.53$ \\
\hline GlcA $\beta 1-3$ GalNAc $(6 S)$ & $18.2 \pm 0.38$ & $15.0 \pm 0.75$ \\
\hline $4 \mathrm{~S} / 6 \mathrm{~S}$ & 0.47 & 0.65 \\
\hline $\operatorname{IdoA} \beta 1-3 \mathrm{GalNAc}(4 \mathrm{~S})$ & $7.25 \pm 0.22$ & $6.18 \pm 0.85$ \\
\hline \multicolumn{3}{|l|}{ Conditioned medium } \\
\hline GlcA $\beta 1-3$ GalNAc & $4.05 \pm 0.24$ & $3.58 \pm 0.13$ \\
\hline GlcA $\beta 1-3$ GalNAc(4S) & $51.2 \pm 1.27$ & $36.0 \pm 1.44^{* *}$ \\
\hline GlcA $\beta 1-3$ GalNAc(6S) & $77.4 \pm 3.35$ & $61.9 \pm 1.36^{* *}$ \\
\hline $4 \mathrm{~S} / 6 \mathrm{~S}$ & 0.66 & 0.58 \\
\hline $\operatorname{IdoA} \beta 1-3 \operatorname{GalNAc}(4 \mathrm{~S})$ & $37.8 \pm 4.38$ & $50.3 \pm 2.64^{*}$ \\
\hline
\end{tabular}

Sparse cultures of bovine aortic smooth muscle cells were incubated at $37^{\circ} \mathrm{C}$ for $24 \mathrm{hr}$ with cadmium $(0.1 \mu \mathrm{M})$. Values are means \pm S.E. of three samples. Significantly different from the corresponding control, ${ }^{*} p<0.05 ; * * p<0.01$.

tion, the metal significantly increased the amount of $\operatorname{IdoA} \beta 1-3 \mathrm{GalNAc}(4 \mathrm{~S})$. These changes appear to be due to the inhibition of versican synthesis and the induction of biglycan/decorin synthesis by cadmium. ${ }^{22)}$ On the other hand, the ratio of GlcA $\beta 1$ $3 \mathrm{GalNAc}(4 \mathrm{~S})$ to GlcA $\beta 1-3 \mathrm{GalNAc}(6 \mathrm{~S})$ was unaffected by cadmium, indicating that the sulfation of GlcA $\beta 1-3$ GalNAc is not influenced by the metal. Thus, it is suggested that cadmium inhibits the synthesis of versican but induces that of biglycan and decorin ${ }^{22)}$ without influence on the formation of their dermatan sulfate chains in sparse vascular smooth muscle cells.

It has been shown that versican is prominent in the diffuse intimal thickening of early atherosclerosis, whereas biglycan and decorin are localized to the fibrous cup of more advanced atherosclerotic lesions ${ }^{25)}$ with changes in the microstructure of glycosaminoglycan chains. ${ }^{26)}$ In the present study, it was suggested that the microstructure of chondroitin/ dermatan sulfate chains of versican, biglycan and decorin would not be changed by lead and cadmium, although the metals may contribute to the accumulation of proteoglycans during the progression of 
atherosclerosis depending on vascular smooth muscle cell density. However, it is also suggested that either lead or cadmium can increase the proportion of IdoA $\beta 1-3 \mathrm{GalNAc}(4 \mathrm{~S})$ in the atherosclerotic vascular wall, depending on vascular smooth muscle cell density, through a decrease in GlcA-containing disaccharide units, and by both a decrease in GlcAcontaining disaccharide units and an increase in IdoA $\beta 1-3 \operatorname{GalNAc}(4 \mathrm{~S})$, respectively.

The present data suggest that lead and cadmium specifically act on the synthesis of chondroitin/ dermatan sulfate proteoglycan core proteins, but not on the formation of their chondroitin/dermatan sulfate chains in the process of proteoglycan synthesis. As a result, the metals may change the composition of chondroitin/dermatan sulfate in the atherosclerotic vascular wall depending on the density of vascular smooth muscle cells. However, interaction of lead and cadmium with cytokines/growth factors, such as platelet-derived growth factor, ${ }^{27)}$ transforming growth factor- $\beta^{28)}$ and tumor necrosis factor- $\alpha^{29)}$ that regulate the synthesis of extracellular matrix composition, remains to be elucidated.

Acknowledgements The present study was partly supported by the Specific Research Fund of Hokuriku University (to T. K.) and by a Grant-inAid for Young Scientists (B) from the Ministry of Education Culture, Sports, Science and Technology (to Y. F.).

\section{REFERENCES}

1) Iozzo, R. V. (1997) The family of the small leucinerich proteoglycans: key regulators of matrix assembly and cellular growth. Crit. Rev. Biochem. Mol. Biol., 32, 141-174.

2) Camejo, G., Hurt-Camejo, E., Wiklund, O. and Bondjers, G. (1998) Association of apo B lipoproteins with arterial proteoglycans: pathological significance and molecular basis. Atherosclerosis, 139, 205-222.

3) Whinna, H. C., Choi, H. U., Rosenberg, L. C. and Church, F. C. (1993) Interaction of heparin cofactor II with biglycan and decorin. J. Biol. Chem., 268, 3920-3924.

4) Järveläinen, H. T., Kinsella, M. G., Wight, T. N. and Sandell, L. J. (1991) Differential expression of small chondroitin/dermatan sulfate proteoglycans, PG-I/ biglycan and PG-II/decorin, by vascular smooth muscle and endothelial cells in culture. J. Biol.
Chem., 266, 23274-23281.

5) Wight, T. N., Heinegard, D. K. and Hascall, V. C. (1991) Proteoglycans: structure and function. In Cell Biology of Extracellular Matrix, 2nd ed. (Hay, E. D., Ed.), Plenum Press, NY, pp. 45-78.

6) Silbert, J. E. (1996) Organization of glycosaminoglycan sulfation in the biosynthesis of proteochondroitin sulfate and proteodermatan sulfate. Glycoconj. J., 13, 907-912.

7) Dingwall-Fordyce, I. and Lane, R. E. (1963) A follow-up study of lead workers. Br. J. Ind. Med., 20, 313-315.

8) Houtman, J. R. (1993) Prolonged low-level cadmium intake and atherosclerosis. Sci. Total Environ., 138, 31-36.

9) Revis, N. W., Zinsmeister, A. R. and Bull, R. (1981) Atherosclerosis and hypertension induced by lead and cadmium ions: an effect prevented by calcium ion. Proc. Natl. Acad. Sci. U.S.A., 78, 6494-6498.

10) Subramanyam, G., Bhaskar, M. and Govindappa, S. (1992) The role of cadmium in induction of atherosclerosis in rabbits. Indian Heart J., 44, 177-180.

11) Yamamoto, C. and Kaji, T. (2002) Induction of plasminogen activator inhibitor type 1 synthesis by cadmium in human vascular endothelial cells in culture. J. Health Sci., 48, 55-61.

12) Kaji, T., Mishima, A., Yamamoto, C., Sakamoto, M. and Koizumi, F. (1992) Effect of cadmium on the monolayer maintenance of vascular endothelial cells in culture. Toxicology, 98, 105-110.

13) Ross, R., Glomset, J. and Harker, L. (1997) Response to injury and atherosclerosis. Am.J. Pathol., 86, 675684.

14) Fujiwara, Y. and Kaji, T. (1999) Lead inhibits the core protein synthesis of a large heparan sulfate proteoglycan perlecan by proliferating vascular endothelial cells in culture. Toxicology, 133, 159169.

15) Fujiwara, Y. and Kaji, T. (2002) Suppression of proteoglycan synthesis by calcium ionophore A23187 in cultured vascular endothelial cells: Implication of intracellular calcium accumulation in lead inhibition of endothelial proteoglycan synthesis. J. Health Sci., 48, 460-466.

16) Fujiwara, Y. and Kaji, T. (2000) Inhibition of the repair of injured endothelial cell monolayers by lead and its possible mechanisms. J. Health Sci., 46, 14.

17) Fujiwara, Y., Kaji, T., Yamamoto, C., Sakamoto, M. and Kozuka, H. (1995) Stimulatory effect of lead on the proliferation of cultured vascular smoothmuscle cells. Toxicology, 98, 105-110.

18) Fujiwara, Y., Watanabe, S. and Kaji, T. (1998) Promotion of cultured vascular smooth muscle cell 
proliferation by low levels of cadmium. Toxicol. Lett., 94, 175-180.

19) Yamamoto, C., Kaji, T., Sakamoto, M. and Kozuka, H. (1996) Effects of cadmium on the release of tissue plasminogen activator and plasminogen activator inhibitor type 1 from cultured human vascular smooth muscle cells and fibroblasts. Toxicology, 106, 179-185.

20) Yamamoto, C., Miyamoto, A., Sakamoto, M. and Kaji, T. (1997) Lead perturbs the regulation of spontaneous release of tissue plasminogen activator and plasminogen activator inhibitor-1 from vascular smooth muscle cells and fibroblasts in culture. Toxicology, 117, 153-161.

21) Fujiwara, Y., Yamamoto, C. and Kaji, T. (2000) Proteoglycans synthesized by cultured bovine aortic smooth muscle cells after exposure to lead: lead selectively inhibits the synthesis of versican, a large chondroitin sulfate proteoglycan. Toxicology, 154, 9-19.

22) Fujiwara, Y., Tsumura, N., Yamamoto, C. and Kaji, T. (2002) Different effects of cadmium on proteoglycan synthesis of arterial smooth muscle cells: increase in small dermatan sulfate proteoglycans, biglycan and decorin, in the extracellular matrix at low cell density. Toxicology, 170, 89-101.

23) Jackson, P. (1994) High resolution polyacrylamide gel electrophoresis of fluorophore-labeled reducting saccharides. Meth. Enzymol., 230, 250-265.

24) Plaas, A. H., West, L. A. and Midura, R. J. (2001) Keratan sulfate disaccharide composition determined by FACE analysis of keratanase II and endo- beta-galactosidase digestion products. Glycobiology, 11, 779-790.

25) Gutierrez, P., O’Brien, K. D., Ferguson, M., Nikkari, S. T., Alpers, C. E. and Wight, T. N. (1997) Differences in the distribution of versican, decorin, and biglycan in atherosclerotic human coronary arteries. Cardiovasc. Pathol., 6, 271-278.

26) Shirk, R. A., Parthasarathy, N., San Antonio, J. D., Church, F. C. and Wagner, W. D. (2000) Altered dermatan sulfate structure and reduced heparin cofactor II-stimulating activity of biglycan and decorin from human atherosclerotic plaque. J. Biol. Chem., 275, 18085-18092.

27) Schönherr, E., Jörveläinen, H. T., Sandell, L. J. and Wight, T. N. (1991) Effects of platelet-derived growth factor and transforming growth factor-beta 1 on the synthesis of a large versican-like chondroitin sulfate proteoglycan by arterial smooth muscle cells. J. Biol. Chem., 266, 17640-17647.

28) Schönherr, E., Järveläinen, H. T., Kinsella, M. G., Sandell, L. J. and Wight, T. N. (1993) Plateletderived growth factor and transforming growth factor-beta 1 differentially affect the synthesis of biglycan and decorin by monkey arterial smooth muscle cells. Arterioscler. Thromb., 13, 1026-1036.

29) Kaji, T., Hiraga, S., Yamamoto, C., Fujiwara, Y., Ueda, Y., Zisaki, F., Iwata, K., Okada, Y. and Katsuda, S. (2002) Effect of tumor necrosis factor$\alpha$ on the synthesis of DNA, the secretion of matrix metalloproteinases/tissue inhibitors of metalloproteinases, and the activity of invasive migration in cultured vascular smooth muscle cells. J. Health Sci., 48, 354-358. 